Revista Eletrônica de Direito Processual - REDP.

Rio de Janeiro. Ano 11. Volume 18. Número 2. Maio a Agosto de 2017

Periódico Quadrimestral da Pós-Graduação Stricto Sensu em Direito Processual da UERJ

Patrono: José Carlos Barbosa Moreira. ISSN 1982-7636. pp. 460-469

www.redp.uerj.br

\title{
NOWHERE FAST? SHORTCUTS TO JUDGMENT IN RECENT ITALIAN PROCEDURAL LEGISLATION ${ }^{1}{ }^{2}$
}

Michele Angelo Lupoi

Professor at University of Bologna, Italy. PhD in Law. miclupoi@ tin.it; micheleangelo.lupoi@unibo.it

RESUMO: o texto trata das medidas adotadas, no Direito italiano, que criaram novas regras procedimentais, com vistas a permitir maior agilidade na prolação de decisões de mérito. Tratou-se, neste trabalho, das novas regras a respeito da concessão de medidas antecipadas de natureza provisória, bem como dos procedimentos sumários para casos mais simples, a possibilidade de conversão do rito comum para os ritos sumários e o novo filtro para os recursos de apelação.

PALAVRAS-CHAVE: direito processual civil italiano; procedimento sumário; duração razoável do processo; conversão de ritos; filtros recursais.

ABSTRACT: The text deals with the measures adopted in Italian law, which created new procedural rules, in order to allow greater agility in the rendering of decisions on merit. This paper deals with the new rules regarding the granting of anticipatory provisional measures, as well as summary procedures for simpler cases, the procedural switch to summary proceedings, and the new filter for appeals.

KEYWORDS: Italian civil procedural law; Summary procedure; Reasonable duration of the proceedings; Conversion of rites; Recursional filters.

SUMMARY: 1 . - Introduction. -2 . An "inflexible" approach to civil proceedings? - 3. Law n. 353 of 1990 and the introduction of procedural preclusions. - 4. New procedural rules for

\footnotetext{
${ }^{1}$ Artigo recebido em 01/05/2017, sob dispensa de revisão.

${ }^{2}$ ) This is the text of a paper presented at a Conference organized by the University of Vilnius on September 30 and October 1, 2016, dedicated to "Ways of implementation of the right to civil proceedings within a reasonable rime"
} 
Revista Eletrônica de Direito Processual - REDP.

Rio de Janeiro. Ano 11. Volume 18. Número 2. Maio a Agosto de 2017

Periódico Quadrimestral da Pós-Graduação Stricto Sensu em Direito Processual da UERJ

Patrono: José Carlos Barbosa Moreira. ISSN 1982-7636. pp. 460-469

www.redp.uerj.br

anticipatory provisional measures. -5 . Summary proceedings for "simples" cases. -6 . The procedural switch to summary proceedings. -7 . A new filter to the appeals. -8 . Final remarks.

1. - For a long time The Italian system of civil justice has been troubled by "time".

I will now state the obvious (and with a very sad heart): Italian proceedings of all sorts tend to be longer than proceedings in other developed countries and they do not comply with the reasonable delay standard set by art. 6 of the ECHR and by art. 111 of the Italian Constitution $\left({ }^{3}\right)$.

They are simply too long, unacceptably long.

There are several causes for this situation and it is beyond the scope of this presentation to analyse them. There are also several ways to try to solve it, as the papers presented at this conference clearly show. For example, this morning, we have heard many presentations dealing with the organization of the courts or with the development of e-proceedings $\left({ }^{4}\right)$. In Italy, by contrast, so far, the legislator appears to be mostly relying on a "procedural approach", on the assumption that proceedings may be made faster and more efficient by changing the rules that govern their development.

In order to tackle this dramatic situation, many (more or less extensive) reforms have been enacted in recent years by the Italian lawmaker, as concern both adjudicative jurisdiction and enforcement jurisdiction.

This paper, in fact, is centred on some procedural devices, which the Italian lawmaker enacted in the past few years in order to try to reduce the duration of civil proceedings. What I aim to present is by far not a complete list of procedural innovations in Italian legislation. It would simply be pointless. On the contrary, my intention is just to provide some meaningful examples of a more general trend in the development of the face of Italian civil justice.

\footnotetext{
${ }^{3}$ ) For a very recent assessment of the situation, see Caponi, The Performance of the Italian Civil Justice System: An Empirical Assessment, in The Italian law journal, 2016, n. 1, p. $15 \mathrm{ff}$.

$\left.{ }^{4}\right)$ Incidentally, it has to be remarked, on a positive note, that electronic proceedings are now a well-defined and successful reality in Italy: as a matter of fact, most interactions between lawyers' and courts in civil litigation develop through the so called electronic "consolle". Moreover, the security standards applied by the Italian legislation with reference to e-proceedings are arguably higher than those commonly accepted in the European setting. So far, however, the development of e-justice does not seem to be accompanied by a shortening of civil proceedings.
} 
Revista Eletrônica de Direito Processual - REDP.

Rio de Janeiro. Ano 11. Volume 18. Número 2. Maio a Agosto de 2017

Periódico Quadrimestral da Pós-Graduação Stricto Sensu em Direito Processual da UERJ

Patrono: José Carlos Barbosa Moreira. ISSN 1982-7636. pp. 460-469

www.redp.uerj.br

Actually, the lawmaker appears to believe that the "procedural solution" will suffice to achieve the aim of shortening the duration of civil proceedings.

The experience with the new devices enacted over more than two decades, however, seems to tell another story: but this is something best left for my final remarks.

2. - As a preliminary remark, it must be pointed out that many Italian academics strongly believe that in order to comply with the fair process requirements set by the Constitution in art. 111, civil proceedings should be fully and analytically regulated by statute, avoiding or strongly limiting any judicial discretion in regards to the organization of the proceedings.

Large sections of the Italian procedural doctrine, actually, express suspicion towards judicial discretion, on the assumption that it cannot be controlled and reviewed and therefore its exercise may infringe on the parties' fundamental rights.

A corollary of such approach is that only fully regulated proceedings should lead to a decision that will become res judicata, i. e. unchangeable.

Arguably, this way of thinking has widely influenced procedural reforms in Italy, making it hard, for example, to introduce a real system of case management as many other Europeans States have.

As a matter of fact, case management implies collaboration between the judges and the parties, within a general framework set by statute, but with wide ranging judicial powers to regulate the course of individual proceedings.

The Italian system of civil procedure, by contrast, has been defined for a long time as "inflexible" and not very concerned with the proportionality principle, which is at the core of important reforms throughout the world.

Fully regulated proceedings, with pre-determined time-limits and phases, actually require "time"", irrespective of the complexity of the case.

3. - The "inflexibility" of the Italian civil procedural system can be clearly found in the most throughout recent reform of Italian civil procedure, brought by law n. 353 of 1990, which basically rewrote entire parts of the code of civil procedure. 
Revista Eletrônica de Direito Processual - REDP.

Rio de Janeiro. Ano 11. Volume 18. Número 2. Maio a Agosto de 2017

Periódico Quadrimestral da Pós-Graduação Stricto Sensu em Direito Processual da UERJ

Patrono: José Carlos Barbosa Moreira. ISSN 1982-7636. pp. 460-469

www.redp.uerj.br

As concerns us here, that reform changed the structure of ordinary civil proceedings by introducing a system of rigid subsequent time limits for all of the activities of the parties. When a given time limit expires, the parties may no longer perform the specific procedural activity related to that time limit (e. g.: the filing of a document): a system of procedural preclusions has thus been enacted.

The original belief of the lawmaker was probably that this strict organization of the development of the procedure would shorten the length of civil proceedings. As a matter of fact, before this reform, it was possible for the parties (rectius, their lawyers) to bring new elements in the case (in particular, new evidence and new defences) over the whole course of first instance proceedings (thus forcing the other party to ask for a postponement of the case in order to examine the new element and raise her defences against it).

Reality has shown that this aim has not been achieved. The parties' activities are nicely structured and punctuated, but the time elapsing from one procedural stage to the next is often unacceptably long (and for reasons not related to the procedural rules themselves).

The system of preclusions is thus only instrumental to an organized development of the procedure but has proved to be unable, in itself, to reduce the duration of civil proceedings.

Moreover, the system of procedural preclusions (in a context where no pre-trial phase exists) not always enables the judge to make the substance of the case prevail over form: preclusions, actually, tend to make the search for "truth" rather elusive.

4. - Interim and provisional remedies are traditionally considered shortcuts to judgment, in the sense that they provide a quick decision, outside of ordinary civil proceedings or within them, but with the aim to preserve or anticipate the protection that those proceedings should provide with the final judgment.

Provisional remedies in Italy have also been reformed in 1990, by law n. 353, with a very successful set of new procedural rules (procedimento cautelare uniforme).

The reform confirmed the instrumental nature of provisional remedies, in the sense that they are not an independent form of judicial protection of rights: on the contrary, they try to make proceedings on the merits effective and efficient by protecting the right 
Revista Eletrônica de Direito Processual - REDP.

Rio de Janeiro. Ano 11. Volume 18. Número 2. Maio a Agosto de 2017

Periódico Quadrimestral da Pós-Graduação Stricto Sensu em Direito Processual da UERJ

Patrono: José Carlos Barbosa Moreira. ISSN 1982-7636. pp. 460-469

www.redp.uerj.br

adjudicated upon during the course of the proceedings and before the final judgment has been rendered.

Such instrumental nature, even after the reform of 1990, was considered a necessary feature of provisional remedies: as a matter of fact, the original rules of law n. 353 made it always compulsory for a party which was granted ante causam provisional remedy to bring proceedings on the merits within a peremptory time limits of 30 days. When that limit was not respected, the provisional remedies would become ineffective.

A provisional remedy, moreover, would become ineffective if proceedings on the merits were started but subsequently were struck out for failure to perform procedural activities (estinzione). In other words, after the reform of 1990 (as it was before), provisional remedies could not stand alone and always had to be connected to pending (or soon-to-be pending) proceedings on the merits.

It could thus happen that the party that had been granted the provisional remedy had lost interest in the decision on the merits but still had to pursue the proceedings in order to avoid the provisional remedy from becoming ineffective. When one thinks about proceedings in default of the defendant, this situation appears to be rather surreal.

Thus, one could say that strict instrumentality was a factor in the global overcharging the backlog of the courts.

In 2005 12006, the lawmaker brought an important innovation in this area of the law.

The distinction between conservative and anticipatory remedies, previously only elaborated in academic writings, was implemented into the procedural system.

Today, there are two procedural tracks in relation to provisional measures: strict instrumentality still is enforced vis à vis conservative measures, which preserve a situation but offer no actual satisfaction of the applicant's claim (like sequestration of the debtor's assets). On the other hand, anticipatory measures, which provide for unstable but immediate relief (the claimant gets what the claimant wants, but on a provisional basis), are treated differently. Today, when an anticipatory measure (e.g., a provvedimento d'urgenza: an urgent measure under art. 700 c.p.c.) is granted ante causam, the winning party is no longer compelled to bring proceedings on the merits. 
Revista Eletrônica de Direito Processual - REDP.

Rio de Janeiro. Ano 11. Volume 18. Número 2. Maio a Agosto de 2017

Periódico Quadrimestral da Pós-Graduação Stricto Sensu em Direito Processual da UERJ

Patrono: José Carlos Barbosa Moreira. ISSN 1982-7636. pp. 460-469

www.redp.uerj.br

In other words, the interim measure may stand alone, though as a provisional and never final decision, which may be overturned should proceedings on the merits be started at any time.

The same happens when an anticipatory measure is issued, proceedings on the merits are started and subsequently are struck out. In this case too, the anticipatory measure still stands.

The idea behind this reform is that, when an applicant has obtained a measure which provisionally grants the type of relief he applied for, that applicant has no real interest in bringing or further cultivating proceedings on the merits. Res judicata is only relevant for academics, not for the common people who apply for fast, efficient and effective relief.

The same may be said about the other party, who may not be willing to further litigate the issue after having lost the "preliminary battle" (possibly with high legal costs...).

Therefore, no party will spend time and money in proceedings that nobody is really interested in and the State will be happy because scarce judicial resources will have been spared.

It is very hard to verify whether this reform has contributed in reducing the number of cases going to court (therefore making it possible for judges to dedicate more time to dispatching pending cases). As a matter of fact, counting the number of cases which could have gone to court but didn't, because both parties' were somehow satisfied by the anticipatory decision, is not an easy task.

One possible side effect (and an unwanted one...) of this reform, however, is that judges, aware of the stronger impact of anticipatory measures, may now be less willing to grant them and more demanding as concerns the requirements for their approval (fumus boni iuris and periculum in mora).

5. - In 2009, another major procedural reform was enacted (law n. 69) in the constant attempt to try and reduce the duration of civil proceedings.

Arts. 702-bis ff. were thus brought into the code of civil procedure, introducing the new summary ascertainment proceedings (procedimento sommario di cognizione).

The basic idea is that, in regard to simpler cases, which fall to be decided by a single judge of the Tribunale (Main court of first instance), it is possible to conduct the proceedings 
Revista Eletrônica de Direito Processual - REDP.

Rio de Janeiro. Ano 11. Volume 18. Número 2. Maio a Agosto de 2017

Periódico Quadrimestral da Pós-Graduação Stricto Sensu em Direito Processual da UERJ

Patrono: José Carlos Barbosa Moreira. ISSN 1982-7636. pp. 460-469

www.redp.uerj.br

in a less formal way, in particular as concerns the way the evidence is gathered and the parties' activities are organized.

The law does not specify when a case may be considered "simple" in this context: academics and practitioners tend to agree, however, that a case may be dispatched in a summary (i. e. de-formalized way) when the facts on which the decision has to be given are not in dispute or if the necessary evidence may be gathered in a quick way (e. g.: only a couple of witnesses has to be heard).

These proceedings may be summary, but the final decision is not: on the contrary, first instance proceedings are decided with a final order (ordinanza) which, however, has the function of a judgment and, like a proper judgment, has to be appealed against within a peremptory dead-line or it become res judicata under art. 2909 c.c.

The main characteristic of these new proceedings is that they may be started as summary proceedings by the claimant. but it is up to the judge, at the first hearing, to decide whether the case is suited for a summary decision or, rather, it is deemed to be too complex: if that is the case, the proceedings leave the summary tracks and are turned into ordinary proceedings (were full formalities will be enforced).

Some academics have strongly criticized these new "alternative" proceedings, mostly because they are considered not to comply with the Constitutional requirements of fair trial since their course is not strictly regulated by statute and the judge's discretion plays a stronger role than in ordinary proceedings.

My opinion is that these proceedings provide for a challenge to both the parties and the judge, to be able to cooperate with each other in agreeing on a less formal and therefore quicker course of the proceedings when the case does not require a lot of evidence to be gathered. Procedimento sommario may actually be considered a form of embryonic Italian case management, even though we are still way behind other countries in this concern.

Summary proceedings, however, have so far proved to be a failure, in the sense that they are very little used in practice. The reasons for this failure are several: lawyers are always suspicious about new procedural devices and tend to avoid using them unless they are obliged to; judges, on the other hand, appear to be too ready to turn summary proceedings into the ordinary tracks, either because the case is more complex than the claimant suggested, or because it is a solution which enables the judge to postpone the decision of the case. After 
Revista Eletrônica de Direito Processual - REDP.

Rio de Janeiro. Ano 11. Volume 18. Número 2. Maio a Agosto de 2017

Periódico Quadrimestral da Pós-Graduação Stricto Sensu em Direito Processual da UERJ

Patrono: José Carlos Barbosa Moreira. ISSN 1982-7636. pp. 460-469

www.redp.uerj.br

all, to be able to say that a case is a "simple one", a judge has to appear at the first hearing with a fair understanding of the case itself. And most civil judges, in our congested courtrooms, simply do not have time to do that.

6. - The Italian lawmaker, however, seems to have a lot of trust in the capacity of deformalized proceedings to speed up the duration of civil cases.

As a matter of fact, in 2014, in one more redrafting of procedural rules to try to shorten the length of civil proceedings $\left({ }^{5}\right)$, a new art. 183-bis was introduced in the code of civil procedure.

This new provision sets for a "mirror like" mechanism vis à vis the one I have described in the previous paragraph in relation to summary proceedings.

Here, when ordinary proceedings are started, at the first hearing, the judge is empowered to decide that the case is simple and that it may be conducted in a deformalized summary way, in order to reach a decision faster. When that decision is taken, the case leaves the tracks of ordinary proceedings and follows the rules set by art. 702-ter c.p.c. for summary proceedings.

This new procedural "switch" appears however to be (still) scarcely used in practice, mostly because the procedural mechanisms set forth in art. 183-bis c.p.c. are rather unclear and because, for the same reasons mentioned above as concerns summary proceedings, the judge is not necessarily ready, at the first hearing, to take decisions concerning the complexity of the case.

It has to be noted, however, that, in $2015\left(^{6}\right)$, the lawmaker has attempted to implement the use of both summary proceedings and of the procedural switch of art. 183-bis c.p.c. by making an application to those procedural mechanisms one of the requirements to apply for an equitable compensation for the unreasonable duration of civil proceedings $\left({ }^{7}\right)$. In other

\footnotetext{
5 ) Decreto-legge 12 September 2014, n. 132, converted into law 10 November 2014, n. 162.

$\left.{ }^{6}\right)$ Law 28 December 2015, n. 208, the so-called Legge di stabilità 2016.

${ }^{7}$ ) Under the new Art. 1-bis of the so-called Legge Pinto of 2001, a party has the right to apply for rimedi preventivi (preventive remedies) in order to avoid a violation of the "reasonable delay" principle set in art. 6 of the E. C.H.R. Parties which have applied for such rimedi preventivi but still have suffered a damage deriving from the unreasonable duration of the proceedings are entitled to an equitable compensation. The rimedi preventivi to which art. 1-bis refers are listed in art. 1-ter of Legge Pinto, and, as remarked in the text, among them we find "bringing the claim as a summary proceeding under art. 702-bis c.p.c." and "applying for a procedural switch from ordinary to summary proceedings under art. 183-bis c.p.c.” Art. 2, para. 1 of Legge
} 
Revista Eletrônica de Direito Processual - REDP.

Rio de Janeiro. Ano 11. Volume 18. Número 2. Maio a Agosto de 2017

Periódico Quadrimestral da Pós-Graduação Stricto Sensu em Direito Processual da UERJ

Patrono: José Carlos Barbosa Moreira. ISSN 1982-7636. pp. 460-469

www.redp.uerj.br

words, the party that does not prove to have tried to use all of the devices which could fasten the course of the proceedings, may not later complain for the excessive length of her trial.

7. - The lawmaker, in recent times, has also tried to reduce the length of appeal proceedings, notoriously long in Italy, especially at the Court of appeal level (in many Courts, cases are dispatched in 4 or 5 years....).

Traditionally, an almost absolute right of appeal has existed in Italy, as concerns both second instance appeals and appeals before the Corte di Cassazione, our Supreme Court. Over time, this has led to a serious congestion of appeal courts of all kinds.

Thus, in $2012\left({ }^{8}\right)$, a new art. 348-bis c.p.c. was brought in the code of civil procedure, introducing the so-called "filter to the appeals" (filtro in appello): in other words, today, at the first hearing before a second instance judge, the latter may dispose of the case in a summary way, simply stating that the appeal has no reasonable chance to succeed.

When that happens, however, all is not lost for the appellant, who is enabled to appeal against the first instance court directly to the Supreme Court. This may appear to an outsider rather odd: that when the doors of the court of appeal close down, those of the Cassation open up. One must consider, however, that under art. 111, para. 7, of the Italian Constitution, an absolute right exists to appeal a decision before the Supreme Court when such decision infringes upon a subjective right and has a "final" nature.

Unsurprisingly, also this new procedural device, which recalls some feature of English civil procedure, has failed to reduce the backlog of Court of appeals.

As a matter of fact, appeal judges have proved to be reluctant to apply this "filter", either to resist the temptation to simply dispose of unwanted new cases (which is good) or because, in order to decide that an appeal has no likely chance of success, one has to study that appeal and be ready to rule upon in at the very first hearing of the case (and not five years later...).

Pinto now peremptorily states that a claim for equitable compensation brought by a party which has not applied for rimedi preventivi under art. 1-ter is inadmissible.

$\left.{ }^{8}\right)$ Decreto legge 22 June, n. 83, converted into Law n. 134 of 7 August 2012. 
Revista Eletrônica de Direito Processual - REDP.

Rio de Janeiro. Ano 11. Volume 18. Número 2. Maio a Agosto de 2017

Periódico Quadrimestral da Pós-Graduação Stricto Sensu em Direito Processual da UERJ

Patrono: José Carlos Barbosa Moreira. ISSN 1982-7636. pp. 460-469

www.redp.uerj.br

8. - In this short presentation, I have tried to point out some recent new features of Italian civil procedure which have been implemented in an attempt to reduce the duration of civil proceedings.

The outcome of all these new devices, unfortunately, is rather disappointing.

Apart from proceedings for provisional measures, which have proved to be a success, so far the lawmaker has not been able to provide mechanisms that really implement its purposes.

Strangely enough, the lawmaker keeps on refusing to introduce proceedings in default, which could lead to a judgment against a defendant which does not appear before the court based on the simple claim of the plaintiff.

Moreover, the legislator has so far been unable (or unwilling) to redraft ordinary proceedings introducing a real system of case management or a pre-trial phase.

As I have hinted in the second paragraph, this may arguably be a consequence of academic suspect towards judicial discretion.

At the end of the day, however, the conclusion that may be reached from the Italian experience in the last $20 \backslash 25$ years is that procedural reforms alone are not enough.

The lawmaker has basically transformed the code of civil procedure into a sort of Frankenstein monster, full of articles bis, ter and quater but no real avail.

Civil proceedings continue of last far too long, notwithstanding all of the reforms and the efforts.

At this point, the lawmaker should have realized that it has to find new ways to try and some this dramatic problem of Italian civil justice.

Start spending more money in a more efficient way in the judicial system might be a good attempt. But every solution which requires more money to be spent is indeed a problem in these times of austerity.

However, one should always remind Albert Einstein's definition of insanity: “doing the same thing over and over again and expecting different results.

This is a lesson the Italian lawmaker should really learn. 